\title{
LA ACTITUD DE LA REAL ACADEMIA ESPAÑOLA PARA LA INCLUSIÓN DE LA ETIMOLOGÍA EN EL DICCIONARIO
}

ENRIQUE JIMÉNEZ RÍOS

Universidad de Salamanca

\section{INTRODUCCIÓN}

La inserción de apartados de historiografía linguística en un programa de historia de la lengua se justifica por el soporte que una lengua tiene o puede tener en gramáticas, diccionarios y obras referidas a la propia lengua (obras normativas como el Appendix Probi o El Dardo en la Palabra). A esta consideración se une el hecho de que los historiadores de la lengua abordemos la historia desde una perspectiva extrema neogramática, concebible para aquellos períodos de la lengua, similares a los de la reconstrucción del indoeuropeo, para los que no se cuenta con medios no sólo gramaticales, sino ni siquiera con recursos escritos. Por esto se ha tardado en introducir en las teorías del cambio el influjo que tienen en él las creencias de los hablantes. Las de los gramáticos y lexicógrafos, se me aceptará que influyen de un modo particular. El paso del tiempo ha ido desvelando que los excesos de método, de cuño neogramático, tenían que contar con factores como la variación, que tan mal se aviene con la regularidad de las leyes fonéticas y con la interferencia de las ideas que los propios hablantes tienen de su lengua.

A estos dos hechos, fundamentales para la historia de la lengua, me voy a referir aquí a través de un acercamiento al diccionario académico: 1) por un lado, un examen muy por encima de sus distintas ediciones servirá para mostrar la existencia de un planteamiento etimológico sobre el léxico que, al igual que se ha visto en Mayans ${ }^{1}$ y en el padre Sarmiento ${ }^{2}$, no puede dejarse de lado como antecedente de la creación de la lingüística histórica como ciencia; 2) por otro lado, como consecuencia de lo anterior, mostraré algunos ejemplos que sir-

\footnotetext{
${ }^{1}$ G. Mayans, Orígenes de la lengua castellana, 1737. Reproducción de la edición facsímil editada en Madrid por Victoriano Suárez, 1873, Valencia, Librería París-Valencia, 1980.

${ }^{2}$ M. Sarmiento, Elementos etimológicos según el método de Euclides (1758-1766). Edición y estudio por J. L. Pensado, A Coruña, Fundación Pedro Barrié de la Maza, 1998.
} 
ven para ver de qué manera la etimología ha determinado el triunfo de alguna de las formas que tenemos hoy en la lengua:

Efecto por efeto; amaste por amastes, sólo explicables por la idea preconcebida gramatical que las ha frenado; del mismo modo que la presión de los cultos frenó quige, quigera por quise, quisiera o vigitar por visitar, porque, como decía Valdés, «por muy mejor tengo la $s$ y creo que la $g$ no la avéis oído usar a muchas personas discretas nacidas y criadas en Toledo o en la corte, si ya no fuesse por descuido» ${ }^{3}$.

Además, me voy a fijar en ejemplos concretos de léxico, como el caso de detentar, detentor, detentador, que hasta la penúltima edición del diccionario formaban un grupo con el mismo significado de 'tomar el poder ilegítimamente'.

Detentor había llegado a ser lo mismo que detentador (de lo que hay muestras incluso en la prensa), cuando en realidad era simplemente el 'poseedor' (como su cognados franceses e italianos), y así lo prueba un ejemplo de un documento navarro. Con buen criterio se ha corregido en la última edición del diccionario y detentor ha sido eliminado ${ }^{4}$.

Errores como éste sólo pueden explicarse a causa de la falta de perspectiva histórica que ha llevado a relacionar en los diccionarios datos de distintas épocas — incluso de diferentes variedades dialectales - y a suponer $-\mathrm{o}$ inventar- un mismo significado para todas las palabras de una misma familia, sin atender a que las diferencias cronológicas y diatópicas pueden originar que la común etimología de un grupo no implique un significado común en todos sus elementos y que puedan existir, por tanto, voces que hayan quedado aisladas de las del resto de su familia.

\section{LA ACADEMIA Y LA FUNCIÓN DE LA ETIMOLOGÍA}

La Academia inicia sus tareas referentes a la lengua española desde su misma fundación, precisamente porque se crea con este fin. La tarea principal que acomete es la de su diccionario. Para ello encuentra un apoyo fundamental en la etimología. Porque ese diccionario no tiene la función que atribuimos en la actualidad a los diccionarios. La lexicografía tal y como se concibe en la Ilustración - lo ha explicado Aitchison - no busca dar cuenta del uso para orientar la elección de los hablantes por los caminos de lo más común, sino que pretende reducir su inseguridad proponiéndoles como modelo el uso de los mejores; el cual, dicho en palabras de la propia Aitchison, es el de las clases medias altas o de las clases altas a secas.

\footnotetext{
${ }^{3}$ J. de Valdés, Diálogo de la Lengua, edición de C. Barbolani, Madrid, Cátedra, pág. 174.

${ }^{4}$ J. A. Pascual, «Detentar entre la norma y el uso», BULAG, Mélanges offerts a Gaston Gross à l'occasion de son $60^{e}$ aanniversaire, PUFC, 2000, págs. 161-179.
} 
Ese deseo del pensamiento ilustrado de que todas las personas tengan las mismas oportunidades se resuelve en el ámbito de lo lexicográfico proponiendo a los hablantes un espejo en que mirarse, que tenía como marco el uso de un determinado grupo social. Esa es la propuesta; otra muy distinta que fuera tarea sencilla lograr integrarse en este modelo digno de imitar: a quienes poniéndose de puntillas intentaban imitar los usos sociales altos, también en materia de léxico, y no lo lograban, la sociedad les reservaba voces que surgen en el siglo XIX, como cursi y hortera; la primera de ellas registrada por vez primera en Galdós y luego en Clarín, por medio de la que se hace referencia a las personas que pretendiendo mejorar de situación social, su comportamiento - linguiístico también - delataba lo postizo de la situación.

Pero no nos fijemos en quienes no logran aprender la lección; dejemos la situación en ese momento en que el diccionario brinda a quien en el siglo de las Luces quiere rentabilizar sus talentos, un refinadísimo código de lo que puede decir y de lo que debe y no debe decir. ¿Se le explica a ese hablante que tal uso es bueno a causa de la clase social que lo practica? Evidentemente no, sino que ese uso es el adecuado porque las personas cultas mantienen los sentidos prístinos de las palabras, en un momento en que — como en todos- se ha atribuido al desinterés de los incultos el cambio lingüístico, enfocado sólo por una de sus causas: el error. Y esos sentidos originales de las palabras se podían establecer prácticamente gracias a la etimología.

La etimología es así, de partida, un argumento para una terapia que los lexicógrafos debían proponer a los hablantes en sus usos: una terapia que orientaba decididamente por los caminos del casticismo. El hecho es tan importante que a casi tres siglos del comienzo de la lexicografía académica se sigue situando en el terreno mismo de la etimología no sólo las razones del buen uso: aunque José Antonio Pascual haya mostrado que 50 profesores universitarios de Filología e Historia empleen detentar en un sentido distinto al que aparece en el diccionario académico, la renuencia a aceptar el cambio está creando un contraste entre el uso y el diccionario, precisamente a causa de ese pensamiento etimológico. Pero el problema trasciende el hecho mismo del uso cuando uno de los elementos que más han aparecido en las discusiones sobre la ampliación del significado de la voz matrimonio en nuestro ordenamiento jurídico ha sido precisamente la etimología.

En esa diferencia entre la lexicografía del siglo XVIII y la que se practica en la actualidad, la etimología - aunque, como hemos visto, puede tomarse como un argumento importante del uso - tiene un valor distinto: hoy puede plantearse una persona si sirve de algo que aparezca mensa como etimología de mesa en el $D R A E$. Digámoslo: incluso los diccionarios que mantienen la etimología en su microestructura, ésta ha perdido esa función ejemplar para justificar el rechazo del cambio, salvo en lo que respecta a los anglicismos, que es un asunto por el que no voy a poder seguir. 


\section{ANTECEDENTES DEL INTERÉS POR LA ETIMOLOGÍA}

Pero la etimología se explica en el primer diccionario académico por otros motivos más: concretamente porque el latín es el lazo de unión entre la antigua lexicografía bilingüe y la naciente monolingüe, pero, sobre todo, es la lengua vehicular que permite acceder desde otra lengua vulgar al castellano.

En este trasvase de la lexicografía bilingüe a la monolingüe se mantenía el latín como mediador, de modo que los primeros diccionarios considerados monolingües son etimológicos: el Origen y Etymología de todos los Vocablos originales de la lengua castellana. Alfabeto primero de Francisco del Rosal, de $1601^{5}$ y el Tesoro de la Lengua castellana o española de Sebastián de Covarrubias, de 1611.

Y es que más que una clasificación de cuño aristotélico de las palabras, tal y como la practica la lexicografía actual, en la Edad Media y el Renacimiento se basaba la definición fundamentalmente en dar con el origo de la palabra, en la línea más pura del pensamiento gramatical latino, institucionalizado por Quintiliano. Claro que para la búsqueda del «origen» no se contaba con un andamiaje científico, como el que cuenta la etimología actual. De ahí que se llegara a situaciones incomprensibles desde nuestras ideas actuales en el dominio de la linguiística histórica, como es el caso de la búsqueda en el hebreo del origen de muchas palabras, por ser considerada la lengua primigenia.

Con todo se observa en el Diccionario de Autoridades una actitud mucho más cauta que en los siglos de Oro, como se percibe en la crítica a Covarrubias:

Es evidente que a este Autor se le debe la gloria de haver dado principio a obra tan grande, que ha servido a la Academia de clara luz en la confusa obscuridad de empressa tan insigne; pero a este sabio Escritor no le fue fácil agotar el dilatado Océano de la Lengua Española, por la multitud de sus voces; y assí quedó aquella obra, aunque loable, defectuosa, por faltarla crecido número de palabras; pero la Real Academia, venerando el noble pensamiento de Covarrubias, y siguiéndole en las voces en que halló proporción y verisimilitud, ha formado el Diccionario, sujetándose a aquellos principios, y continuando después debaxo de las reglas que la han parecido más adequadas y convenientes, sin detenerse con demasiada reflexión en el origen y derivación de las voces: porque además de ser trabajo de poco fruto, sería penoso y desagradable a los lectores, que regularmente buscan la propiedad del significado: y el origen o la derivación, quando no es mui evidente y claro, quedaba siempre sujeto a varios conceptos, después de ser desapacible su lección, y que ocasionaría un volumen fastidioso y dilatado ${ }^{6}$.

${ }^{5}$ F. de Rosal, Diccionario etimológico, 1601, edición facsímil y estudio de E. Gómez Aguado, Madrid, CSIC, 1992.

${ }^{6}$ Real Academia Española, Diccionario de la lengua castellana (Diccionario de Autoridades), Madrid, Francisco del Hierro, 1726-1739, edición facsímil, Madrid, Gredos, 1984, prólogo, pág. I-II. 
La crítica a Covarrubias supone un cambio con respecto al tipo de etimología que se había venido practicando desde la Edad Media: si la característica de alguna de las etimologías del Tesoro es la fantasía ${ }^{7}$, el canónigo de Cuenca no deja de notar la corrupción como causa de la separación entre el latín y el castellano, aunque no se adentra con detenimiento por este asunto, sino que se conforma con una explicación que muestra la mayor distancia que media entre él y la etimología científica, que la que media entre ésta y la Academia:

Y presupuesto que los más vocablos castellanos son corrompidos de la lengua latina, hase de advertir que muy de ordinario se mudan las letras, trocándose unas por otras; y las más ordinarias son las nueve consonantes, que se llaman mutas, divididas en tres clases: tenues, medias y aspiratas. También se mudan las demás, y unas vocales en otras, y esto todo está advertido por algunos autores modernos que han reducido nuestra lengua a método, haziendo arte de gramática española ${ }^{8}$.

La nueva etimología que quiere cultivar la corporación académica, siguiendo el rumbo que marca el siglo ilustrado, está encaminada a mostrar la relación estrecha que mantiene el castellano con el latín en esta importancia que tiene el origo para la definición. La vía para hacerlo está en fijarse más en la forma que en el significado, algo que no será una realidad hasta el siglo XIX, pero que tiene en el XVIII un precedente bien consolidado para ello: basta fijarse para comprobarlo en la labor etimológica de Mayans y de Sarmiento. Son éstos, con independencia del encono entre el primero de ellos y la Academia, quienes influyen en este fuerte giro dado en lo etimológico. Del examen de la relación latín-castellano pueden derivarse reglas que expliquen la evolución y a su enunciación se dedican estos autores junto con la institución académica. Más tarde el jesuita Esteban de Terreros en su traducción de la paleografía de Pluche construye una verdadera historia de la lengua del español, deudora de la de Andrés de Poza, pero frenado en sus excesos.

Pero lo que resulta realmente importante: es la Academia quien liga, por primera vez, la etimología, hasta entonces interesada por buscar la causa o mo-

${ }^{7}$ De Covarrubias, pero también de los que pueden considerarse sus fuentes: Valverde y Rosal. Bartolomé Valverde es autor de un Tratado de Etymologías de voces castellanas en estas Lenguas Latina, Hebrea, Griega, Árabe. (Ms. 9934 de la Biblioteca Nacional de Madrid) cuya extensión es de aproximadamente trescientas entradas. Comienza con unos presupuestos teóricos en los que recomienda para la búsqueda etimológica «acudir a la lengua que últimamente se estendio por España con la Nación que la sugetó [...] Pues no hallándose como digo la etimología del vocablo Castellano en la Arábiga, ni Latina, lo seguro y acertado es acudir a la fuente y madre de todas, la Lengua Hebrea». Vid. Conde de la [Cipriano Muñoz y Rivero], Biblioteca histórica de la filología castellana, Madrid, Imprenta y fundición de Manuel Tello, 1893, tomo III, pág. 1625).

${ }^{8} \mathrm{~S}$. de Covarrubias, Tesoro de la lengua castellana o española, con las anotaciones de R. Noydens, 1611, edición facsímil, México, Turner, 1984, «Al lector». 
tivo de una palabra, a esa preocupación que empieza a surgir por las transformaciones en el significante, en lo que ha de verse un antecedente de la etimología como disciplina científica. Veámoslo con algún detalle.

\section{LA CONSIDERACIÓN ACADÉMICA DE LA ETIMOLOGÍA}

Para hallar el origen de un vocablo los académicos prefirieron empezar por el latín como lengua base del castellano («el Etymologico Español no debe subir mas arriba la Genealogía de sus Voces, que hasta sacarlas de la Lengua matriz, de donde inmediatamente nacen» ${ }^{9}$ ). Pues aunque todo el pensamiento precientífico anterior al surgimiento de la linguiística histórica nos parece uniforme, hay serias diferencias entre las ideas linguiísticas del Renacimiento y las de la Ilustración. Para los ilustrados resultaba evidente el principio occammiano (es decir, de Occam), que luego adoptó Spitzer en materia etimológica, según el cual había que preferir la hipótesis más sencilla en vez de la más brillante. Y la hipótesis más sencilla era -y sigue siendo— el latín.

En 1726, fecha de la publicación del primer tomo del Diccionario de Autoridades, la Academia expone el modo como debe tratar la etimología en la obra, pues todo buen diccionario tenía que incluir entre sus informaciones la etimología de las voces:

Por lo que mira a las Etymologías hace la Academia la misma ingenua expresión [que en la ortografía: «es mui grande el descuido o ignorancia que se padece»], como se reconocerá por el discurso de ellas, que en adelante se pone. Habla la Academia de las Etymologías con el pulso y moderación que corresponde al peligro de errar: y tiene por más congruente evitar muchas, antes que exponerse a un error cierto, que justamente se le impugnase ${ }^{10}$.

Pulso y moderación —otra característica de la manera de proceder los ilustrados en este terreno- resumen la postura con que la Academia se enfrenta a la etimología y expresan asimismo la dificultad para determinarla (en la prólogo de la $2^{\mathrm{a}}$ edición del Diccionario de Autoridades de 1770 se insiste en la misma idea: «De las etimologías se han escusado las improprias, violentas o inciertas, poniendo sólo las que han parecido más propias, naturales o fundadas» ${ }^{11}$ ). Las consecuencias de este interés ya las he adelantado: la posibilidad de purificar de este modo la lengua castellana ${ }^{12}$.

\footnotetext{
${ }^{9}$ Diccionario de Autoridades, Discurso proemial sobre las etimologías, pág. LII.

10 Prólogo, pág. V.

11 Prólogo, pág. VII.

12 Habla la Academia en el $\$ 10$ del Discurso proemial sobre las etimologías de cómo la etimología de las voces, entre otras enseñanzas, «podía tocar a limpiar, fijar y dar esplendor a la
} 
Al método etimológico se refieren los académicos en el Discurso proemial sobre las etymologías que sigue al prólogo. En este discurso, el primero de esta naturaleza que encontramos en el ámbito hispánico, expone la Academia su concepción de la etimología, la situación en que se encuentra su cultivo y la manera como debe ser tratada.

Empieza la corporación por admitir que la relación que se establece entre una palabra y su referente no es natural, sino arbitraria y convencional ${ }^{13}$, pero se trata — podríamos decir — de una arbitrariedad determinada por la propia naturaleza del objeto:

La Etimología de una Voz es el origen, o principio que tuvo para su formación, o significado: y assi el estudio de las Etymologías es procurar saber y descubrir el verdadero origen, o principio de cada voz: pues si bien estas se definen rigurosamente, que son significativas al arbitrio y común consentimiento de los hombres, a estos debemos suponer racionales, y que al tiempo de formar las Voces, mas se movieron por razón, que por capricho: y el fundamento de esta razón es lo que se llama Etymología, por ser la raíz y principio que tuvo la Voz o que tuvo su significación ${ }^{14}$.

Tras las defensa de la etimología como la búsqueda del étimo de una palabra y de su significado primero, como búsqueda de la verdad («este estudio es útil por el intento de descubrir y apurar la verdad» ${ }^{15}$ ), se adentra la Academia en demostrar su utilidad, su validez y su consideración como disciplina científica, cuyo cultivo exige mucha reflexión y un vasto conocimiento por parte de quien lo practica. Era una defensa de la etimología dada la consideración que se tenía de ella, como muestran las siguientes palabras de Quevedo:

En el origen della [lengua castellana] han hablado algunos linajudos de vocablos, que desentierran los huesos a las voces, cosa más entretenida que demostrada; y dicen que averiguan lo que inventan ${ }^{16}$.

Lengua» (pág. LI). Por su parte La Viñaza dice que «encarece la Academia el estudio de las etimologías y su gran importancia. Para el significado de las voces y para la perfecta ortografía, dice con razón ser su estudio importantísimo» (op. cit., Libro III, pág. 1500).

${ }^{13}$ La lingüística española del siglo XVIII se ocupa, entre sus temas fundamentales, de determinar cuál es el origen del lenguaje. Para ello se tiene una postura platónica y aristotélica, que en unos autores se inclina más hacia el platonismo y en otros hacia el aristotelismo: la primera postura toma el Génesis como punto de referencia habitual para explicar el primer acto de nominación (véase, por ejemplo, G. Mayans, Orígenes § 1); la segunda, defiende que, a la explicación de las palabras primitivas como signos naturales, se unen las palabras convencionales, palabras creadas ad placitum, que, dejando de lado consideraciones naturalistas, pueden estar condicionadas o motivadas.

${ }^{14}$ Discurso proemial sobre las etimologías, pág. XLVIII.

${ }^{15}$ Discurso proemial sobre las etimologías, pág. L.

${ }^{16}$ F. de Quevedo, «Cuento de Cuentos», en Obras Completas I, Madrid, Aguilar, 1961, pág. 366 
La forma y el significado de una palabra son su objeto de atención y así lo demuestra cuando dice:

Este torrente de bien poderosas autoridades tiene que vencer la ligereza de aquellos, que por contentarse con el vago sonido de una Voz (cuyo significado imaginan que entienden) les parece estudio superfluo y vano la penetración de la propriedad, pureza y naturaleza de la Voz y su significación ${ }^{17}$.

O cuando en este otro apartado, al hablar de la bondad del trabajo etimológico en relación con otras disciplinas, afirma:

Que todas las Ciencias son buenas, y que lo es el estudio de las Lenguas, su perfección, y su penetración, y en ellas el estudio y aplicación de las Etymologías, como medio essencial para conocer las Voces y penetrar su sonido ${ }^{18}$.

Ejemplifica su postura defensora de la etimología con un método formado por diez Reglas para determinar adecuadamente la etimología de una voz:

La primera, segunda y séptima tratan sobre la alteración que la forma de una palabra puede experimentar con el transcurso del tiempo:

La primer regla que debe observar el Etymológico es atender a la significación de la Voz, y confrontarla con la significación de la voz matriz: porque si convienen las dos Voces, no hai mayor seña de la filiación que el común significado, aunque se diferencien en mucho las letras: pues esta diversidad de letras puede ser variación por las causas que se dirán en la regla siete y la común significación es indubitable seña del origen: assi se ve en estas voces Obra, que viene de Opera, aunque solo convengan en la O, R y A: Hijo, que viene de Filius, y solo conviene en la I.

Sea la segunda regla la que nos da la misma Voz Filius, y es atender a la configuración de la Voz, que bien examinada, no suele tener mas que una, u otra letra común; pero en el todo de ella se halla tal relación con la matriz, que ninguno puede dudar de su filiación, siendo uno mismo el significado: esto se ve en muchas Voces. Sean exemplo Hijo de Filius, Páxaro de Paser, Apremiar de Premere, y assi otros muchos.

La séptima regla, y más dilatada, es atender mucho a la variación de las letras, porque con el uso, y la mayor facilidad de pronunciar unas por otras, o con el deseo de suavizar las Voces, se han commutado unas letras por otras, de donde se han desfigurado las Voces: y esto no solo al salir de la Lengua matriz, sino aun después de estar ya introducidas, y proprias las Voces en la Lengua Española: como se reconoce en la voz Hijo, que al salir de la Latina sin duda fue Fillo, como aun dicen los Asturianos, de allí se mudó a Fijo y de allí a Hijo, y en la voz Desahuciar, que arriba queda explicada, y en la voz Conseillo, que se ha mudado en Consejo, y de otras muchíssimas: como se reconoce, confrontando los libros antiguos con los modernos: y como esta

\footnotetext{
17 Discurso proemial sobre las etimologías, pág. XLIX.

18 Discurso proemial sobre las etimologías, pág. L.
} 
mutación de letras, o substitución de unas en otras no es objeto, ni materia propria de la Gramática, y toca mui essencialmente a la Etymologia, es preciso expresarla con la mayor claridad, siguiendo en esto el exemplo del célebre Etymológico Menage, que con esta sola advertencia ilustró su libro y este fue el único proemial que juzgó necessario ${ }^{19}$.

[Vid. infra el Desarrollo de la regla séptima]

Es decir, lo que los neogramáticos formularon como las palabras con una previsible relación semántica en que se cumplían unas reglas en paralelo.

La tercera regla trata sobre la conveniencia de leer los textos del pasado para documentar las primeras modificaciones, cercanas a la base latina, que haya sufrido una voz. Esto sigue siendo hoy un proceder básico del trabajo de investigación en el ámbito de la historia de la lengua:

La tercera regla es leer y examinar los libros antiguos y en ellos reconocer las Voces, porque muchas al principio salieron mui semejantes al matriz, y luego se han ido variando; y aunque su configuración denota la raíz, se haze más patente sabiendo la primer Voz de donde se corrompió, o se pulió la que ahora se usa. Sea exemplo la Voz Consejo, que en lo antiguo del Consilium Latino se uso mui frequentemente Conseillo: de Fugere decimos oy Huir, suavizando el antiguo Fugir, que usa siempre el Fuero Juzgo, y la Chrónica general, y assi otros muchos ${ }^{20}$.

La cuarta, quinta, sexta y octava reglas tratan sobre la participación que tiene la morfología flexiva y derivativa en la investigación etimológica: la recomendación académica es analizar la voz fijándose sólo en la raíz, pues la terminación es resultado de la adaptación de la palabra a la lengua romance. En realidad, en el pensamiento gramatical de los siglos XVIII y XIX, las referencias a la etimología corresponden a lo que ahora se conoce como morfología derivativa, o si se prefiere, como morfología léxica. Y hay que decir, que en este tercer hecho, frente a los dos anteriores, no es mucho lo que ha avanzado la escuela pidaliana, hasta la aparición del diccionario de Corominas o la obra de Malkiel:

Sea la quarta regla que debe el Etymológico observar el no atender a las terminaciones de las Voces, porque estas son propriedad específica de cada Lengua: y está tan lejos de que ellas puedan dirigir a la raiz, que para inferirla se deben separar, como que ciertamente son adiciones, con las quales convirtió en proprias palabras la Lengua viva, las Voces de otras Lenguas. El exemplo está claro en los adverbios de modo, los quales en nuestro idioma se acaban en mente: como Claramente, cuya terminación separada, queda el adverbio Latino Clare con poca o ninguna mudanza y no puede haver duda de la raíz con sola esta breve reflexión en semejantes adverbios, Confusamente,

\footnotetext{
19 Discurso proemial sobre las etimologías, pág. LVI-LVIII.

${ }^{20}$ Discurso proemial sobre las etimologías, pág. LVII.
} 
Blandamente, Delicadamente, Dulcemente, y otros infinitos. Y esto mismo sucederá en muchos Nombres, como los substantivos acabados en anza, Labranza de Labor. Y en los acabados en is Latino, que en nuestro idioma terminan en L, quitado el is: como Filial de Filialis, Pueril de Puerilis: y es cierto que si se recogieran todas las terminaciones Latinas y Españolas, se pudieran dar unas reglas mui generales para este conocimiento; pero aquí se omiten porque estas terminaciones son proprio objeto de la Gramática y al Etymológico le basta saber que debe separar la terminación para descubrir mejor la raíz.

La quinta regla debe ser el conocimiento de que las Lenguas vivas se nutren, convierten en propria substancia su misma substancia, engendrando nuevas Voces de sus mismas Voces. Esto se ve claro en los Nombres substantivos acabados en ento: como Conocimiento de Conocer, Entendimiento de Entender, Ardimiento de Arder, y al contrario algunos Verbos que nacen de nombres: como Alumbrar de Lumbre, Apestar de Peste, Apesgar de Pesga.

La sexta regla para los Nombres que vienen del Latín, es atender al plural Español y al acusativo del plural Latino. Son muchísimos los que convienen en un todo: como Aras, Ricas, Luces, Vivas, Límites, Divinos, Nobles, Titulares, Amantes, Finos, Tropheos, Patentes, y un sin número de Nombres, que mudando en el singular español la terminación, en el plural (por haver sin duda concurrido las terminaciones Latinas con las antiguas Españolas) hallaron facilidad en tomarlas los Españoles, o por usar en su Lengua las semejantes, o por serle mui fácil a la Lengua aquel modo de pronunciar.

Lo mismo se ve en los Verbos, atendiendo al gerundio, pues en ellos, o no se diferencian, o se acercan los nuestros mucho a los de la Lengua matriz: como Amado, Adorando, Dando, Leyendo, Ofreciendo, Muriendo, y assi con poca reflexión otros muchos.

La octava regla sea observar con cuidado y reflexión las partículas compositivas, assí en Nombres, como en Verbos, porque estas no vienen de la Lengua matriz: y es menester separarlas de la Voz, para conocer mejor su origen $^{21}$.

La novena regla trata sobre el origen que muchas palabras tienen en una contingencia, que con el paso del tiempo puede llegar a olvidarse, que es precisamente esa zona — pensemos, de nuevo, en la voz cursi, por ejemplo- que sigue siendo un problema en la etimología actual:

La regla nona es la experiencia de que muchas Voces tienen su origen en una contingencia, y anguna historia, la qual como con el tiempo se olvida, es bien difícil, y aun imposible apurarla, no haviendo especies que la exciten: y esto en muchas Phrases es freqüente. El exemplo está claro en esta Voz Bisoño, que ya en nuestra Lengua significa soldado nuevo, porque en la guerra de Italia, quando passaron allá los Españoles, como no practicos en la Lengua Italiana, para pedir lo que necesitaban decían: Bisoño pan, bisoño carne, que vale tanto como he menester pan, he menester carne, \&c. y así los Italianos

${ }^{21}$ Discurso proemial sobre las etimologías, pág. LX. 
dieron en llamarlos Bisoños, y de ahí quedó este nombre a los Soldados nuevos, por serlo en aquel tiempo los Españoles, quando usaban desta $\mathrm{Voz}^{22}$.

Y, por último, la décima regla trata del reconocimiento explícito de la arbitrariedad como factor de creación léxica, lo que sigue siendo el problema básico con que cuenta la semántica histórica:

La regla decima, y última sea la consideración de que muchas Voces han nacido tan legítimas del absoluto imperio, o tyranía del uso, que es imposible hallarlas raíz, por no conocer otra madre, que el gusto, y uso de los hombres: y assí en estas es forzoso que ceda el discurso a la razón, sin empeñarse en descubrir raíz, quando repassando las reglas dichas no se encuentra, porque es cierto que muchas Voces no la tienen. Esta regla nos la dictó S. Isidoro, quien después de las que dio para inquirir las Etimologías, concluye: Algunas voces se engendraron, no según su qualidad, sino solo por el arbitrio libre de los hombres, y no se les conoce otra raíz. Esto está expuesto a una mui natural contingencia de que algún Etymológico no encuentre más raíz de una Voz, que el arbitrio libre, y el uso común, y otro, u de ingenio más vivo, u de viveza más dichosa, encuentre en otra Lengua raíz clara; pero este inconveniente es ninguno, pues solo nace de la diversidad de los ingenios, y en toda Facultad se tropieza con esta experiencia ${ }^{23}$.

Digámoslo claramente: el punto de partida de la labor académica en lo referente a la etimología se ha de insertar - como ocurre con la labor de Mayans o Sarmiento - antes del pensamiento científico neogramático; pero hay que destacar que cumple los mismos planteamientos básicos de ese pensamiento.

El problema es la falta de unas leyes fonéticas que permitieran - como ocurre con la aplicación de cualquier método científico- hacer avanzar el modelo. No, fue suficiente para un tipo razonable de trabajo; pero no contribuyó a ese desarrollo del método científico a que me he referido. Precisamente la regla séptima se relaciona con las que luego serían las leyes fonéticas, es decir, la etimología. Tomando como modelo y fuente al etimólogo francés Giles Menage ${ }^{24}$, la Academia expone los cambios que experimentan las letras en el paso del latín al castellano y lo hace de una manera muy metódica y muy explícita ${ }^{25}$ :

La $O$ se suele mudar en UE: como Corda Cuerda, Forum Fuero, Hospes Huésped, Mola Muela, Porta Puerta, Sporta Espuerta.

La $U$ en $O$ como Furca Horca, Gulosus Goloso, Ulmus Olmo, Stupa Estopa, Musca Mosca y las primeras Personas del plural en los Verbos.

${ }^{22}$ Discurso proemial sobre las etimologías, pág. LX.

${ }^{23}$ Discurso proemial sobre las etimologías, pág. LX.

${ }^{24}$ Sus obras fundamentales son Le origini della Lingua Italiana (Ginebra, 1685) y el Dictionnaire Etymologique ou Origines de la Langue Française, publicado en 1650. En esta edición del Dictionnaire aparece un «Discours sur la Science des Etymologies» seguido de unos «Principes de l'Art des Etymologies ou Exemples de la diverse alteration des lettres».

${ }^{25}$ Discurso proemial sobre las etimologías, pág. LVIII. 
La $A U$ se muda en $O$ : como Aurum Oro, Caulis Col, Maurus, Moro.

La $E$ se muda freqüentemente en IE: como Certus Cierto, Servus Siervo, Herba Hierba, Sinistra Siniestra, Terra Tierra, Fera Fiera.

La $I$ en E: como Infirmus Enfermo, Lignum Leño, Sicus Seco, Signum Seña. La $B$ en $P$ [sic], pues según Quintiliano se confunden tanto en la pronunciación, que sin ofender el oido se pronuncia una por otra. Priges Latino, según el mismo, se dixo por mucho tiempo Briges; y assi los Españoles las mudamos muchas veces al respecto de su origen Latino: como Apricus Abrigo, Capra Cabra, Capillus Cabello, Caput Cabeza, Capere Caber, Opera Obra, Sapor Sabor.

La $B$ se muda en $D$ : como Cubitus Codo, Dubitare Dudar, Palpebrae Parpados.

A la $C$ y la $G$ las concede parentesco San Isidoro y se truecan con facilidad, tomando una por otra: como Dico Digo, Acutus Agudo, Amicus Amigo Hac Hora Agora, Mica Miga.

$C L$ se muda en dos $l l$ con nuestra especial pronunciación, Clamare Llamar, Clavis Llave.

Quando en el Latin a la $C$ se sigue $T$, la $T$ se convierte en $H$, y tiene la pronunciación Cha, Cinctus Cincho, Dictus Dicho, Factus Hecho, Lectum Lecho, Lucta Lucha, Nocte Noche, Octo Ocho, Pectus Pecho.

La $D$ se consume o se pierde muchas veces, lo que los Latinos usaron en su propria Lengua, Cadere Caer, Fides Fe, Excludere Excluir, Audire Oir Radius Rayo.

La $F$ se ha mudado en $H$, o aspiración, sin mas fin que la suavidad, Filius Hijo, Facere Hacer, Facienda Hacienda, Fervor Hervor.

La $G$ se muda en $I$ quando no se pronuncia $G$ : como Regnum Reino: y también se pierde muchas veces para suavizar la Voz: como Digitus Dedo, Frigus Frío, Sagita Saeta, Vagina Vaina.

La $L$ en $J$ : como Allium Ajo, Articulus Artejo, Alienum Ajeno, Folium Hoja, Consilium Consejo.

La $L$ con la $R$ son convertibles: como Arbores Arboles, Cerebrum Celebro, Periculum Peligro.

La $N$ se añade, y se quita: como Insula Isla, Ruminare Rumiar, Salnitrum Salitre, Sponsus Esposo, Macula Mancha.

La pronunciación particular de las dos $n n$ por $\tilde{n}$ nace de dos $n n$ : como Annus Año, aunque también suele salir de otras letras: como de Aranea Araña, de Autummus Otoño, de Hispania España, de Dammnum Daño, de Vinea Viña: y como esta es pronunciación nacional propria, se ha acomodado, según que la Lengua se proporcionó a ella, o según la dificultad que encontraban los Españoles en la pronunciación Latina.

La $P$ se muda en L muchas veces, quando en la Voz Latina a la $P$ se sigue $L$, para pronunciar Lla, lle, lli, llo, llu: como Plaga Llaga, Plantus Llanto, Planus Llano, Plenus Lleno, Ploro Lloro, Pluvia, Lluvia.

La $G$ y la $Q$ son tan parientas según San Isidoro, que las confunden los labios, y assi por Equus decimos Igual, por Aliquis Alguien, por Antiquus Antiguo, por Aqua Agua, por Aquila Aguila.

El mismo, y aun mayor parentesco logran la $T$, y la $D$, Catena Cadena, Factum Hecho, Latus Lado, Natare Nadar, Pietas Piedad, Vita Vida. 
Debese empero advertir que estas mutaciones no suceden generalmente en todas las Voces, sino en algunas, porque en otras se conservan las matrices sin la menor variación.

Es mui usado, y mui introducido en la Lengua mudar letras, o añadir a las que avía la $L$, y la $R$, líquidas después de $B$, para suavizar la pronunciación de Amirabilis, Laudabilis, acabados en ilis, Admirable, Laudable, de Homo Home, y de aquí Hombre.

$\mathrm{Y}$ en otras varias ocasiones se hallan mudadas letras de otras Voces, añadiendo, o quitando letras, de las quales no es posible dar más reglas que las dichas, porque no es general la mudanza, y se puede bastantemente conocer la Etymología, observando las reglas que hasta aquí se han escrito: como de Particeps Aparcero, esto es aparticero que quitado el ti queda aparcero, mudada la terminación. Aparejar de Parare, Acordar de Recordari, y otros muchissimos.

No es ésta la Gramática histórica de don Ramón Menéndez Pidal; pero no tiene esta red de reglas nada que ver con el dominio de la fantasía. Tengámoslo en cuenta.

Con el recurso a estas reglas, es como la Academia puede sentar fundadamente la raíz del vocabulario castellano de procedencia latina, remontándose sólo a esa lengua, lo que supone un paso decisivo con respecto a la explicación que el origen del castellano había suscitado en los siglos xvi y XVII ${ }^{26}$. Latín y etimología singularizan así el primer diccionario académico.

Cita a este respecto José Antonio Pascual ${ }^{27}$ la idea del protagonista de Tristram Shandy de Sterne como justificación de lo forzado de las explicaciones etimológicas en la lexicografía de la Ilustración; pero es preciso matizar que en esto hubo una cierta diferencia entre la lexicografía de las lenguas románicas y las otras, por cuanto en nuestras lenguas resultaba factible contar con unos resultados etimológicos — se contaba con el latín y con su documentación-; bastaba con que esos diccionarios estuvieran bien planteados y contaran con personas capaces de dar con estas relaciones, como de hecho contó el primer diccionario académico.

\section{ETIMOLOGÍA Y CORRESPONDENCIA LATINA}

La importancia del latín en esta obra se debía también a su condición de metalengua; es decir, de lengua por la que poder relacionar los signos lingüísticos en un momento en que no se contaba con una teoría sobre la definición y

${ }^{26}$ La búsqueda etimológica también resulta criticada porque se pierde en ir en busca de lenguas exóticas que hayan podido dar lugar a las palabras. A partir de ahora el latín se convierte en modelo y límite para buscan las etimologías.

27 J. A. Pascual, La historia como pretexto, discurso de ingreso en la Real Academia Española, Madrid, Real Academia Española, 2002, pág. 38. 
ésta no era sino una explicación que pretendía hacer entender la realidad léxica descrita, a la manera como se pretendía explicar esa realidad que los marinos tenían que encontrar en los derroteros. Precisamente el desarrollo de las técnicas de definición — que pretenden ser parecidas en las distintas lenguas - tiene algo que ver con la desaparición del latín como metalengua de la lexicografía. A este respecto su situación es parecida a la que hoy tienen en bastantes diccionarios las designaciones científicas de los nombres de animales o plantas... Son, como se ve, los restos razonables de un método lexicográfico que había empezado empleándose en la lexicografía bilingüe:

En la versión Latina de las voces ha procurado poner la Academia la mayor conformidad; aunque muchas veces es casi imposible convertir igualmente la voz Castellana en otra Latina, por cuya razón para inteligencia de los extranjeros se ha usado de algunas phrases en los casos que ha sido preciso, con el deseo de la mayor claridad, y conocimiento de los Lectores: y también por evitar no volver la voz Española en otra Latina, menos expresiva, y no tan correspondiente $^{28}$.

Fijémonos en que la referencia a los extranjeros es lo que justifica hoy una serie de principios de lexicografía y aquí es, como decíamos, un proceder propio de la lexicografía bilingüe.

La versión latina o correspondencia latina era una traducción de la palabra castellana al latín ${ }^{29}$ : más exactamente de cada uno de sus significados; cuando no era posible una traducción adecuada de la voz castellana se recurría a la explicación por medio de una frase.

Si nos fijamos en el modo como se recoge la etimología y la correspondencia latina en el diccionario vemos que las dos aparecen precedidas de la abreviatura lat. detrás de la definición y antes de la autoridad literaria ${ }^{30}$. Hay voces con etimologías, voces con correspondencia latina y voces con etimología y correspondencia latina:

28 Diccionario de Autoridades, Prólogo, pág. VII.

${ }^{29}$ En algunos casos la traducción es de la definición o del sinónimo que sirve para definir la voz. Vid., por ejemplo, abatear: 'lo mismo que lavar' Lat. Lavare, Abluere o ajeno 'lo que es proprio, lo que toca y pertenece a otro. Viene del Lat. Alienus, que significa esto mismo', pero en otra de sus acepciones 'vale también lo mismo que ignorante, o falto de conocimiento de alguna cosa'. Lat. Inscius, Ignorans.

${ }^{30}$ Sobre la abreviatura lat. se dice en el prólogo de la $2^{\text {a }}$ edición de Autoridades, de 1770, lo siguiente: «La nota lat. que se halla en la primera impresión puesta delante de todas las correspondencias latinas se omite ahora porque impresa como está en el mismo carácter redondo que las demás voces, se confunde con ellas y no llama la atención: lo que no sucede con la voz latina impresa con letra bastardilla, como ahora se ha puesto, pues así queda bastantemente perceptible, siendo costumbre distinguir con este carácter las voces latinas en el contexto de otro idioma: a que se añade que muchas de las dicciones a que se antepuso la referida nota no son latinas, sino puramente griegas». 
Palabras con etimología:

Abrego. Lat. Africus, $i$.

Ajenar. Lat. Alienare

Ajeno. Viene del lat. Alienus, que significa esto mismo, por cuya razón se debe escribir con $\mathrm{j}$, aunque mui comúnmente se halla con $\mathrm{g}$.

Actor. Es voz puramente latina. Lat. Actor.

Actitar. Viene del latino Actitare. Lat. Actitare causas.

Acumular. Viene del Latino Cumulare que significa esto mismo.

Palabras con correspondencia latina:

Abreviador. Lat. Cuiusvis operis, aut orationis contractor.

Acertijo. Lat. Aenigmatis.

Acontado. Lat. Fultus.

Acontecimiento. Lat. Causus. Eventus.

Acostamiento. Lat. Stipendium.

Palabras con etimología y correspondencia latina:

Abeja. Viene del lat. Apis que vale esto mismo. Lat. Apis, Apicula.

Abreviación. Es tomado del latino Breviarium Lat. Epitome, Compendio. Contractio.

Ajenador. Lat. Alienator, is. Venditor.

Acumular. Viene del Latino Cumulare que significa esto mismo. Lat. Coacervare, Aggregare.

Adivinación. Es del Lat. Divinatio. Lat. Divinatio. Vaticinatio. Praesagitio. Praedictio.

Ador. Es formado del Lat. Adoras. Lat. Tempus praefixus irrigationibus agrorum.

El distinto modo de recoger la etimología y la correspondencia latina se observa en la información adicional que hay en la etimología: la explicación «es tomado de», «viene de» o simplemente «de» — aunque el caso más claro es aquel en el que se dice «voz puramente latina», que no aparece en las correspondencias-, sirvió para establecer la filiación entre el étimo latino y su derivado castellano.

La función de la etimología había quedado expuesta en el Discurso proemial (así como la dificultad para recogerla); la de las correspondencias latinas, en el texto citado más arriba. En él se refiere la Academia al carácter práctico del diccionario, pues las correspondencias servían «para inteligencia de los extranjeros» y eran una huella de la lexicografía bilingüe y plurilingüe de los siglos XVI y XVII ${ }^{31}$. Y es una idea en que se insiste en el prólogo de la $2^{\mathrm{a}}$ edición

${ }^{31}$ Vid. las Reglas para la confección del diccionario de 1743, pág. X. En el prólogo de la $2^{\mathrm{a}}$ edición del Diccionario de Autoridades se insiste en esta idea: «El intento de la Academia en las correspondencias latinas ha sido dar a conocer a los estrangeros las voces que compehende el Diccionario: y para conseguirlo con toda la perfección posible se pone la voz propia y rigurosa- 
del Diccionario de Autoridades y en los prólogos de las primeras ediciones del diccionario reducido a un tomo ${ }^{32}$.

El problema de esta explicación reside en el hecho de que estamos ante un diccionario monolingüe en el que la macroestructura está formada por voces castellanas. Si tomamos las correspondencias latinas como la vía para contener dentro de este diccionario monolingüe otro bilingüe castellano-latín, se trataría de un diccionario unidireccional, es decir, de una obra en la que la lengua de partida sería únicamente el castellano (que tenía una gran deuda con el diccionario de Covarrubias).

La ayuda que podría suministrar a los extranjeros, como a los propios españoles, exigía dos condiciones: el conocimiento previo de un buen nivel de español, así como del latín ${ }^{33}$. No nos engañemos: la lexicografía moderna, que en

mente latina, siempre que la hay, y en su defecto la que el uso común tiene admitida, aunque sea de la baxa latinidad o nuevamente inventada. Quando faltan voces latinas correspondientes a las castellanas, se usa de circunloquios, especialmente en aquellas que son proprias y peculiares de nuestro idioma, para facilitar su inteligencia a los estrangeros. Y de semejantes circunloquios se usa en otros modos de hablar que no tienen equivalente en latín, pues siempre es mejor poner a estas voces y modos de hablar algún latín con que se expliquen, quando no le hay proprio, que dexarlos sin ninguno, privando a los extrangeros del medio de entender su significación».

${ }^{32}$ En el prólogo de la $5^{\text {a }}$ edición son varias las referencias a la etimología y a las correspondencias latinas: la explicación de la reducción del Diccionario de Autoridades a un solo tomo con la supresión de autoridades y etimologías, la supresión de etimologías que han parecido poco necesarias y oportunas y la observación de «algún descuido en las correspondencias latinas, que desde la primitiva formación del Diccionario quiso la Academia que acompañasen a las palabras castellanas, tanto por hacer participantes de la utilidad del Diccionario a los extrangeros y facilitar entre ellos el conocimiento de nuestra lengua, como por mostrar, según sucede frequentemente, la etimología y origen de nuestras voces. En los más de los artículos pertenecientes a Historia natural se ha puesto la correspondencia latina señalada por el célebre Linneo; y en los de objetos comunes y muy conocidos se ha expresado el nombre que les dieron los autores clásicos romanos o los naturalistas de la media edad. La premura con que se ha hecho la edición, no ha permitido que la corrección en este punto sea tan completa y uniforme como pudiera desearse; pero se han señalado correspondencia a varios artículos que carecían de ellas todavía, y se han mejorado muchas de las restantes».

$\mathrm{Y}$ en el prólogo de la $7^{\mathrm{a}}$ edición también se insiste en la utilidad de las correspondencias latinas para los extranjeros: «Como el uso, árbitro y juez del lenguaje, no sólo admite y desecha voces, sino que suele variar la acepción de las mismas, ocasionando así grandes dificultades para comprender lo que en rigor significan, tomó la Academia desde el principio para fijar más bien el significado de las palabras el medio de poner en seguida las correspondencias latinas. No es necesario detenerse a manifestar la utilidad de este método, no solo para los extrangeros que busquen la significación que ignoran de las palabras, sino tambien para los naturales, especialmente cuando una palabra tiene varias acepciones, como por experiencia podrá cualquiera conocer»..

${ }^{33}$ Con anterioridad a la Academia, el Tesoro de Covarrubias ya se quiso ver como útil para dar noticia de la lengua castellana a los extranjeros. En la carta del licenciado Baltasar Sebastián Navarro de Arroyta que va al comienzo del diccionario éste dice que «esta obra de las Etymologias ha de dar noticia a los estrangeros del lenguage español y de su propiedad y elegancia, que es muy gran honor de la nación española». De donde parece entenderse que la finalidad de la obra no es servir como diccionario bilingüe para los extranjeros, sino ser un instrumento para dar 
el ámbito del español nace con el Diccionario de Autoridades, poco tiene que ver con la actual, en que existen obras para escolares, para extranjeros, junto a un tipo como el diccionario académico, para personas cultas. En el siglo XVIII se contaba con esta última situación, que era la que condicionaba metodológicamente un trabajo de este tipo e indirectamente facilitaba la traducción de la palabra definida al latín, en un momento en que esta lengua gozaba todavía de la condición de lengua de expresión en ámbitos como el de la Universidad o de la iglesia ${ }^{34}$.

Pero además de eso, para lo que sí le sirvió a la Academia la correspondencia latina fue para disimular el desconocimiento de la etimología de una voz, entendida como raíz: si a comienzos del siglo XVIII estaba empezando a plantearse una etimología científica en la que no se cayera ni en el error ni en la divagación, la manera de evitar esa confusión la proporcionaba perfectamente

conocer los rasgos singulares de la lengua española: su propiedad, su elegancia y su filiación con otras lenguas.

Lo que sí podía resultar útil a los extranjeros era la existencia de un vocabulario multilingüe similar al que encontramos como apéndice del diccionario de Terreros. En la edición moderna del diccionario de Terreros, el cuarto tomo está reservado a las correspondencias. El título es el siguiente: «Los tres alfabetos francés, latino e italiano con las voces de ciencias y artes que les corresponden en la lengua castellana. Tomo cuarto y último del diccionario del P. Estevan de Terreros y Pando, 1793». El tomo está dividido en tres partes: italiano-español, francés-español y latín-español. Dicho tomo va precedido de una advertencia en la que el editor, continuador de la obra del jesuita, señala lo siguiente: «Quando por Real Orden se concluyó la edición del Diccionario Castellano de Artes y Ciencias que dexó incompleto el Padre Estevan de Terreros, pensaron los editores que no podía llegar el caso en que vieses la luz este tomo IV, y aun creimos que no era parte principal de la obra. [...] Este tomo IV comprehende, pues, las voces de Ciencias y Artes en las tres lenguas Francesa, Italiana y Latina, cuyas correspondencias expresó el Padre Terreros en el Diccionario Castellano y es en efecto la reducción de éste a aquellos, obra que premeditó el Autor, y que con justísima razon la llama en el Prólogo el complemento a todas sus ideas. Se han distinguido y separado los tres vocabularios Francés, Italiano y Latino siguiendo constantemente en todos ellos la regla general de poner la voz de cada idioma con todas, o el mayor número de las sinonimas, y de varia significación, que la corresponden en castellano. Como la mayor utilidad de este tomo consiste en que se preste auxilio a los Españoles estudiosos para la inteligencia de los libros técnicos de Ciencias y Artes que estén escritos en alguna de las tres lenguas contenidas en él, me he contentado con expresar desnudamente las correspondencias castellanas sin explicación alguna de estas mismas: porque si a consequencia de esta expresión se hubiese explicado el término en cada Diccionario, sería una repetición fastidiosa, hubiera crecido considerablemente la edición y lo que ahora es un tomo, aunque bastante voluminoso, tal vez pasaría de dos o tres de igual volumen» (Tomo IV, pág. III).

${ }^{34}$ En un momento en que el latín era ya una lengua desconocida por una amplia mayoría, a pesar de haber repartidas entre las treinta y dos universidades españolas unas cuatro mil cátedras dedicadas a su enseñanza. Con fecha 11 de septiembre de 1735 un decreto real establece que «ni profesores ni alumnos hablan latín en el recinto de la universidad; por lo cual, ordena el restablecimiento de esta costumbre, tanto en el trato universitario como en los ejercicios de oposición, señalando severos castigos a los que faltaren» (cito por F. Lázaro Carreter, Las ideas lingüísticas en España durante el siglo XVIII, Barcelona, Crítica, 1985, pág. 164). 
la correspondencia latina, pues sólo era necesario atender a la semejanza de significado y no a la posible evolución del significante.

\section{LA SITUACIÓN DE LA ETIMOLOGÍA EN LAS PRIMERAS EDICIONES}

Pero veamos una consecuencia de este doble juego que proporciona el latín: como empezó a hacerse uso de la correspondencia latina en el lugar de la etimología o de una u otra indistintamente, ambas terminaron confundiéndose y en el paso del Diccionario de Autoridades a la $1^{\text {a }}$ edición hubo de eliminarse la etimología en beneficio de la correspondencia latina ${ }^{35}$. Es una sorpresa de la que no logra sacarnos el prólogo de esta edición:

La Academia ha mirado siempre como el primer objeto de sus tareas la corrección y aumento del Diccionario [...] Deseando hacerle de más fácil uso y que el público pueda tenerle por un precio cómodo, determinó reducir los seis tomos a uno solo, pero sin quitar ninguna voz [...] Se han quitado todas las autoridades, etimologías de las voces y anomalía de los verbos, dexando solo la voz, definición y correspondencia latina ${ }^{36}$.

Es una de las consecuencias de la pretensión que perseguía la Corporación, de hacer una obra más manejable y de un precio más asequible; y esa idea se mantiene en las cuatro primeras ediciones, que en esencia son la misma primera edición, con la colocación en el lugar correspondiente del material revisado, que había aparecido primero como suplemento.

Pero es difícil aceptar la redacción de la obra como explicación de la supresión de las etimologías, máxime cuando se mantienen las correspondencias latinas. Más parece ésta una excusa para no afrontar la dificultad que suponía ocuparse de ellas, en una institución que tenía plena conciencia de la importancia, pero de la dificultad a la vez, de la etimología. La doctrina etimológica expuesta en el prólogo de Autoridades no deja lugar a dudas sobre esto.

¡Mala época para la etimología ésta de las cuatro primeras ediciones del diccionario! En la $5^{\text {a }}$, de 1817, se explica que «se han suprimido [...] las etimologías que han parecido poco necesarias y oportunas» ${ }^{37}$, cuando en realidad no se hacía uso de etimologías desde la $1^{\text {a }}$ edición, sino de correspondencias lati-

$35 \mathrm{Si}$ el motivo para la supresión de las etimologías fue la necesidad de reducir el espacio, hubiera sido más razonable la supresión de las correspondencias, más abundantes en el Diccionario de Autoridades y de mayor extensión, pues en algunos casos obligaba a escribir una frase latina. Esta idea que justifica la reducción y supresión de etimologías se repite en los prólogos de las tres primeras ediciones.

36 Real Academia Española, Diccionario de la lengua castellana, Madrid, Joaquín Ibarra, 1780, facsímil de la $1^{\text {a }}$ edición, Madrid, Espasa Calpe, 1991, Prólogo.

${ }^{37}$ Real Academia Española, Diccionario de la lengua castellana, Madrid, Imprenta Real, $5^{\mathrm{a}}$ edición, 1817, Prólogo. 
nas. Esto o lo atribuimos a un error, o la etimología y la correspondencia latina se habían terminado mezclando (sólo en algunos casos: cuando la correspondencia latina era una sola palabra).

En la $7^{\text {a }}$ edición, de 1832 , en plena discusión sobre las razones para la aceptación o no de los vocablos —es decir, en plena euforia de un casticismo en el que aún estamos inmersos - se habla de fijar el significado propio de una voz por la vía de la correspondencia — de la correspondencia latina - con una palabra del latín clásico:

Como el uso, árbitro y juez del lenguaje no sólo admite y desecha voces, sino que suele variar la acepción de las mismas, ocasionando asi grandes dificultades para comprender lo que en rigor significan, tomó la Academia desde el principio para fijar más bien el significado de las palabras el medio de poner en seguida las correspondencias latinas. No es necesario detenerse a manifestar la utilidad de este método, no sólo para los extrangeros que busquen la significación que ignoran de las palabras, sino también para los naturales, especialmente cuando una palabra tiene varias acepciones, como por experiencia podrá cualquiera conocer ${ }^{38}$.

Era el camino más seguro para dar con la propiedad del uso, en un período histórico en el que los hablantes tomaban el cambio como una consecuencia indeseada de la corrupción. Por ello, en la $8^{a}$ edición, de 1837, la Academia ofrece al público otra nueva, en la cual se han hecho mejoras notables, tanto por el aumento de voces castellanas y correspondencias latinas, cuanto por la corrección de muchas definiciones ${ }^{39}$.

Y en la siguiente, en la $9^{\mathrm{a}}$ edición, de 1843 , a pesar de que el diccionario no recoge etimologías, sino correspondencias latinas, recurre a la etimología para determinar si una voz ha de ser admitida o no en el diccionario:

Para haber de deslindar en esta incesante fluctuación las palabras que deben considerarse como dignas de aumentar el caudal del habla castellana de las intrusas y desautorizadas, cuya inundación, nunca mayor que en nuestros días, se ha difundido desde los papeles periódicos hasta el taller de los artesanos, es preciso consultar muchas obras, extractar y comparar autoridades, investigar etimologías hasta donde sea posible, meditar y pesar desapasionadamente los reparos de la crítica y observar en todas sus clases la tendencia de nuestra sociedad en orden a adoptar tales voces o locuciones ${ }^{40}$.

\footnotetext{
${ }^{38}$ Real Academia Española, Diccionario de la lengua castellana, Madrid, Imprenta Real, $7^{\mathrm{a}}$ edición, 1832, Prólogo.

${ }^{39}$ Real Academia Española, Diccionario de la lengua castellana, Madrid, Imprenta Nacional, $8^{\text {a }}$ edición, 1837, Prólogo.

${ }^{40}$ Real Academia Española, Diccionario de la lengua castellana, Madrid, Imprenta F. M ${ }^{\mathrm{a}}$ Fernández, 9a edición, 1843, Prólogo.
} 
No es desacertado pensar que desde la $5^{\text {a }}$ edición hasta ahora, la etimología y la correspondencia latina hubieran difuminado tanto sus fronteras, que hubiera llegado a utilizarse un término u otro indistintamente.

\section{EL ABANDONO DE LAS CORRESPONDENCIAS LATINAS Y LA VUELTA A LAS ETIMOLOGÍAS}

Hay que esperar a la $11^{\text {a }}$ edición del diccionario, de $1869^{41}$, para encontrar, si no la incorporación de la etimología, abandonada unos 90 años antes (en 1780), al menos su defensa. Pero más que por la etimología en sí, porque las correspondencias latinas, resto del planteamiento conservador de Covarrubias, resultaban difíciles de mantener, por las críticas que estaban teniendo estas «graciosísimas equivalencias latinas» —con ese adjetivo sarcástico las caracteriza Fernández Merino en 1889 - ${ }^{42}$. Pero no debemos olvidar la crítica que ya le había hecho Mayans a la corporación en este asunto, pues llegó a afirmar que «[los académicos] padecen de incapacidad de expresarse en lengua latina» ${ }^{43}$, crítica que como se está viendo no fue tenida en cuenta.

Por fin prende en el pensamiento académico la idea de que las correspondencias latinas hacían aguas por todos sitios, tal y como lo muestra el propio prólogo de la $11^{\text {a }}$ edición:

La mayor novedad que respecto a las ediciones anteriores ofrece la presente, es la supresión de las correspondencias latinas. Estas adolecían de algunas inexactitudes inevitables $\mathrm{y}$, sin poder hacer las veces de un Vocabulario hispano-latino, ocupaban grande espacio, y sobre todo podían inducir a error.

Tampoco podrían servir de seguro guía para la etimología de las voces castellanas, por cuanto el mayor número de estas procede del latín vulgar, y las correspondencias se tomaban del clásico. Ni era posible otro arbitrio en punto a la muchas voces representativas de objetos nuevos, de usos y costumbres

${ }^{41}$ Real Academia Española, Diccionario de la lengua castellana, Madrid, Manuel Rivadeneyra, $11^{a}$ edición, 1869, Al lector.

${ }^{42}$ Las correspondencias latinas habían empezado a ser objeto de crítica por parte de estudiosos de fuera de la Academia. A. Fernández Merino, Observaciones críticas a las etimologías de la Real Academia Española, Extracto de la Revista Contemporánea, Madrid, Tipografía de Manuel G. Hernández, 1889, pág. 12, se refiere a ellas cuando habla del diccionario académico: «diremos que de la misma manera que en algunas ediciones anteriores lo más digno de llamar la atención eran las graciosísimas equivalencias latinas»; y, al mismo tiempo, defiende la vuelta a la etimología: «en la última edición lo que más alboroza son las etimologías puestas a gran número de palabras, pues si bien es cierto que analizadas dejan mucho que desear, no lo es menos que con ellas ha ganado grandemente la estética del libro».

43 A. Tovar, «Mayans y la filología en España en el siglo XVIII», Mayans y la Ilustración, Simposio internacional en el bicentenario de la muerte de Gregorio Mayans, Valencia, Ayuntamiento de Oliva, 1981, págs. 379-408. 
modernas, sin equivalentes en latín y que era forzoso explicar por medio de largas y enojosas perífrasis ${ }^{44}$.

Con esto la $11^{\mathrm{a}}$ edición se queda sin correspondencias y sin etimología. Pero es comprensible, pues el lento establecimiento de la etimología del vocabulario castellano, tanto tiempo suprimida, hacía imposible sustituir una información por otra. Sin embargo, en esta edición ya se habla de que se estaba preparando la vuelta a la etimología; en el mismo prólogo recién citado, leemos que

Tales consideraciones, y la de estarse ocupando la Academia en la formación de un Diccionario Etimológico que consigne el origen, la formación y las vicisitudes de cada vocablo, la han movido a suprimir las referidas correspondencias ${ }^{45}$.

Fijémonos en la fecha de esta edición décimoprimera: 1869; veamos cuál es la de la siguiente, la $12^{\text {a }}$ edición: 1884 . De los años sin etimología a su recuperación se ha producido un cambio histórico decisivo: el nacimiento de la lingüística histórica como disciplina científica y la nueva consideración de una etimología no deudora de la fantasía, lo que encajaba bien con una tradición académica razonable, a diferencia del pensamiento gramatical de los siglos XVI y XVIi, en materia etimológica.

Llegamos con ello a la $12^{\mathrm{a}}$ edición, de 1884 , donde se incorporan de nuevo las etimologías ${ }^{46}$ y se hace con toda clase de cautelas, por parte de los académicos — la nómina es representativa: León Galindo y de Vera, Gaspar Núñez de Arce, Marcelino Menéndez Pelayo, Juan Valera-. En el prólogo se expone que:

En la de 1869 omitió, razonando su acuerdo, las llamadas correspondencias latinas que siempre había llevado el libro y ahora, en vez de tales correspondencias, da las etimologías de los vocablos españoles, pero lejos de estimar del todo acabado y perfecto su trabajo en tan ardua materia, no ve en él sino tentativa sujeta a corrección. La necesidad de llevarle a cabo perentoriamente para que por mucho tiempo no careciese el público de este Diccionario, cuya última edición estaba agotada, ha sido la causa de que en la nueva no se atribuya etimología ninguna a voces de origen que no se podía desentrañar sin más largo y feliz estudio. En caso de duda ha parecido preferible, a omitir la etimología, darla con signo de interrogación. Si filólogos españoles o extranjeros hicieran acerca de esta peligrosa labor útiles observaciones, la Academia se complacería de aprovecharlas ${ }^{47}$.

${ }^{44}$ Diccionario de la lengua castellana, $11^{\text {a }}$ edición, 1869, Al lector.

${ }^{45}$ Ibíd.

${ }^{46}$ M. Alvar Ezquerra, «Los prólogos del diccionario académico. Nomenclatura específica y microestructura», RFE LXIII, 1983, págs. 205-222, concretamente, pág. 213 dice que esta actitud fue seguida por la mayoría de los diccionarios posteriores.

${ }^{47}$ Real Academia Española, Diccionario de la lengua castellana, Madrid, Gregorio Hernando, $12^{\mathrm{a}}$ edición, 1884, Advertencia. 
Estamos ante una actitud coherente con el pensamiento científico del momento, que lleva a una importante labor fuera de la misma Academia. Basta citar obras como el Diccionario etimológico de la lengua castellana de Pedro Felipe Monlau, de 1856, posiblemente el mejor diccionario etimológico del siglo XIX ${ }^{48}$.

A partir de entonces, en la $13^{a}$ edición, de 1899, la institución académica se afana por perfeccionar esta parcela del diccionario:

La Academia se ha dedicado con toda asiduidad a perfeccionar su obra en cuanto le ha sido dable, rectificando etimologías... ${ }^{49}$

para lo que empieza a contar con el concurso de personas expertas en esta materia y cuyo reconocimiento se hace patente en el prólogo de la obra:

Que la obra de pulir y enriquecer la lengua castellana se ha hecho popular, lo patentiza el extraordinario aumento que para esta edición ha tenido la corporación de personas y corporaciones diversas, así en España como en América. Entre ellos, merecen que se renueve la especial mención de sus nombres nuestros correspondientes españoles el P. Fidel Fita y D. Agustín de la Paz Bueno, aquél por su constante y fructuosa labor en la Comisión de Etimologías, éste por los inestimables servicios que desde hace más de treinta años viene prestando en la Comisión de Diccionario ${ }^{50}$.

\section{LA CONSOLIDACIÓN DE LA ETIMOLOGÍA}

Nos acercamos al final de esta crónica etimológica. Una crónica que nos lleva a la consolidación de la etimología — científica - en el diccionario. La $14^{\text {a }}$ edición, de 1914, sirvió para desarrollar las ideas expuestas años antes en la $12^{a}$ edición, al tiempo que para perfeccionar y mejorar la obra:

Pero desde que decidió enriquecer el Diccionario con las etimologías de las voces castellanas, ya en la edición anterior y más especialmente en la que ahora saca a la luz, encaminó sus esfuerzos con verdadero empeño a consolidar esta que fue notable mejora en el plan de nuestro léxico, investigando nueva y detenidamente los orígenes de todas las voces en él catalogadas; comprobando a la luz de la más severa crítica las etimologías que parecerían más o menos discutibles, rectificando aquellas para quienes se descubría más sólido fundamento; suprimiendo las pocas que lo tenían algo inconsistente o problemático, y añadiendo número considerable sobre las muchas indiscutibles comprendidas en las dos últimas ediciones ${ }^{51}$.

\footnotetext{
${ }^{48}$ G. Haensch, Los diccionarios del español en el umbral del siglo XIX, Salamanca, Ediciones Universidad de Salamanca, 1997, pág. 112.

${ }^{49}$ Real Academia Española, Diccionario de la lengua castellana, Madrid, Hernando y Cia, $13^{\mathrm{a}}$ edición, 1899, Advertencia.

50 Ibíd.

51 Real Academia Española, Diccionario de la lengua castellana, Madrid, Sucesores de Hernando, 14 ${ }^{\mathrm{a}}$ edición, 1914, Advertencia.
} 
Con ello se inicia una renovación estimulada por dos hechos fundamentales: la presencia de don Ramón Menéndez Pidal en la Academia (otros miembros son, por ejemplo, Francisco Commelerán y Gómez y Francisco Rodríguez Marín), y las críticas de los investigadores encargados de reseñar la obra. Precisamente estos dos miembros que he citado fueron muy críticos con la Academia.

En la reseña a esta edición, la $14^{\mathrm{a}}$, Américo Castro pedía superar los errores etimológicos, pese al trabajo que reconocía que había hecho la corporación en este sentido ${ }^{52}$; lo mismo hizo en su reseña a la $15^{\text {a }}$ edición, de 1925 , publicada ese mismo año:

Para la Academia no existen diccionarios etimológicos, ni leyes lingüísticas, ni gramática histórica. Dejemos a la docta corporación la responsabilidad de tan extraño proceder. En cuanto a crítica de métodos, me remito a mi citada reseña, que, en muy escasa medida, tuvo en cuenta la Academia ${ }^{53}$.

Unos años más tarde, a propósito de la $17^{\text {a }}$ edición, de 1947, Samuel Gili Gaya insistía en la desatención a las etimologías y exponía la situación en que se encontraba su tratamiento, así como el modo de afrontar los cambios:

El retraso que más resalta en las ediciones impresas en el siglo actual se halla en el aspecto etimológico. La gran masa de las etimologías responde a una época anterior a la constitución sistemática de la Lingüística romance. Establecer el origen de una palabra era entonces un tanteo casuístico sin normas fijas ni leyes generales. A esta masa general de etimologías tradicionales fue añadiendo la Academia bastantes correcciones procedentes de las establecidas por Federico Diez, y algunas tomadas de fuentes más modernas, pero siempre como aportaciones sueltas de los académicos, que, si bien han mejorado cierto número de artículos, distan mucho de la revisión completa que el Léxico oficial necesita. Claro está que no vamos a pedirle que registre etimologías que están todavía en discusión, ni puede esperarse que una corporación halle por su cuenta etimologías que no han sido establecidas. Esta labor monográfica está por naturaleza encomendada a la iniciativa exploradora e individual de los investigadores. Pero sí sería de desear un poco más de diligencia en recoger las que se hallan establecidas en firme y son ya de dominio general $^{54}$.

Sí fueron tenidas en cuenta estas críticas a la luz de lo que se dice en la edición $18^{\text {a }}$, de 1956. Vuelve la Academia a hablar de la etimología — no podía ser de otra manera - para decir que

52 A. Castro, «Sobre la $14^{\mathrm{a}}$ edición del Diccionario», RFE, II, 1915, págs. 52-55.

53 A. Castro, «Reseña a Real Academia Española, Diccionario de la Lengua Española, $15^{a}$ edición, Madrid, Espasa Calpe, 1925», RFE, XII, 1925, págs. 403-409.

${ }^{54}$ S. Gili Gaya, «Reseña a Real Academia Española, Diccionario de la Lengua Española, $17^{a}$ edición, Madrid, Espasa Calpe, 1947», RFE, XXXI, 1947, págs. 202-209. 
se han rectificado con arreglo a los últimos resultados de la investigación en esta rama de la lingüística [...] Como este diccionario no es especialmente etimológico, ha sido forzoso prescindir en él de explicaciones que en algunas etimologías serían necesarias, y no se puntualiza, en la mayoría de los casos, la complicada historia de muchas palabras, para determinar, por ejemplo, si tal término griego ha entrado en el castellano directamente o a través de otra lengua; si tal vocablo latino ha pasado a nuestro caudal léxico a través del mozárabe o sin este intermediario, etc., etc. ${ }^{55}$

Además de Pidal, desde mediados de siglo eran académicos especialistas en la materia: Vicente García de Diego y Dámaso Alonso (la presencia de Miguel Asín Palacios, Manuel Gómez Moreno y Emilio García Gómez explica las observaciones a propósito de la etimología árabe).

Pero, sobre todo, se había producido un hecho decisivo en la lexicografía española: la construcción de la base de un diccionario histórico, cuyo inicio se sitúa en 1933 y se retoma en 1947 con la fundación del Seminario de Lexicografía bajo la dirección de Julio Casares. Para un proyecto de esta naturaleza era fundamental contar con la etimología.

Paralelamente a este diccionario, continúa el trabajo del usual. A Casares y a García de Diego se les encarga la redacción de la 19 a edición. Para entonces era posible disponer de los diccionarios etimológicos de Vicente García de Diego y, sobre todo, de Joan Corominas. La deuda con este último no es reconocida hasta la $20^{\text {a }}$ edición, de 1984 :

Las etimologías se han revisado en infinidad de casos. La ciencia etimológica aplicada a nuestra lengua cuenta con trabajo tan útil y ejemplar, y realizado con gran perfección, como es el que hace años publicó el ilustre filólogo catalán Joan Corominas. La Academia agradece a su obra la corrección de muchas etimologías y una información siempre admirable aun cuando a veces mantenga su criterio ${ }^{56}$.

Sólo así se entienden las cautelas para el tratamiento de la etimología, expuestas en las páginas preliminares del diccionario histórico:

La parte etimológica está tratada con sobriedad y cuando ponemos una etimología que está en desacuerdo con la generalmente admitida, procuramos fundamentarla brevemente (véase el artículo abogar). En casos particularmente dudosos colocamos la etimología entre interrogaciones ${ }^{57}$

55 Real Academia Española, Diccionario de la lengua española, Madrid, Espasa Calpe, $18^{a}$ edición, 1956, Preámbulo.

56 Real Academia Española, Diccionario de la lengua española, Madrid, Espasa Calpe, $20^{\text {a }}$ edición, 1984, Preámbulo.

${ }^{57}$ Real Academia Española, Diccionario histórico de la lengua española, Madrid, Espasa Calpe, Fascículo 1, 1960, pág. IX. 
Y años más tarde, cuando aparece el prólogo que cierra el tomo primero, en 1972, señala que

A continuación de la forma clave y de sus variantes, damos entre paréntesis la etimología que creemos sólidamente establecida. Cuando para una palabra los etimólogos han supuesto diversas procedencias, sometemos a crítica las diferentes hipótesis, pero no reflejamos en el diccionario la discusión, limitándonos a dar la etimología que preferimos. Si aun esta nos parece ingenua, la ponemos con interrogante, con el nombre de quien la propuso o con ambas reservas. Lo mismo hacemos cuando no hay controversia, pero tampoco plena conformidad por nuestra parte. No damos etimología si estimamos inadmisibles las que se han propuesto o carecemos de base para formularlas por nuestra cuenta. No entra en nuestros fines investigar el origen de las palabras, aunque no rehusamos la posibilidad de fijarlo siempre que aparezca de manera obvia ${ }^{58}$.

El resultado de este nuevo modo de proceder, por parte de la Academia, conecta con la postura con que inició su interés por la etimología, expresado en el prólogo del Diccionario de Autoridades —un diccionario, no está de más decirlo, inicio de lo que habría de ser un diccionario histórico- pues son, de nuevo, el pulso y la moderación los criterios que guían su trabajo etimológico.

\section{REPERCUSIÓN LINGÜÍSTICA DE LA ETIMOLOGÍA}

Llegados aquí hemos de preguntarnos si este pensamiento etimológico académico termina en el diccionario. Ciertamente no, sino que tiene consecuencias sobre la propia lengua. Vamos a verlo en la última parte de esta exposición.

Para empezar una actuación etimológica como la de la Academia no sólo trata de dirigir su mirada al origen, sino de frenar las reinterpretaciones que hacen los hablantes, equivocados por la etimología popular. Como dice Silvain Auroux en La raison, le langage et les normes, «el léxico más que la sintaxis es el espacio lingüístico de la variación individual». A esta «reinterpretación» que el hablante ve entre enervar y nervio es a la que se dirige la etimología, para frenar un cambio que, visto desde otro punto de vista, es un disparate.

Es una actuación que permite el pensamiento etimológico, cuando el cambio no se ha extendido por todas partes, como lo ha hecho en la actualidad enervar 'poner nervioso' o la pronunciación cónclave frente a la etimológica concláve.

La etimología es a este respecto un argumento para las tensiones entre la norma, no un juez dirimente. Un argumento que debería servir precisamente

58 Prólogo al Diccionario histórico de la lengua española, Marid, Espasa Calpe, tomo I, 1972, reimpreso en R. Lapesa, Léxico e Historia. II Diccionarios, Madrid, Istmo, págs. 41-61, concretamente, pág. 53. 
como elemento formativo para que la gente actúe con más seguridad en asuntos de lengua.

Cuando formamos monokini a partir de bikini (El País, 17.8.2000) o triquini («el triquini no se consolida por su escasa practicidad» (La Gaceta de Salamanca 29.5.2005), no nos damos cuenta de que bi- o tri- no tiene nada que ver con 'dos', 'tres', sino que su origen está en la isla de Bikini, de donde procede la palabra.

La etimología permite, también, explicar contradicciones de significado, cuando en distender tenemos:

1. 'Aflojar, relajar, disminuir la tensión'

2. Med. 'Causar una tensión violenta en los tejidos, membranas, etc.'

En estas dos acepciones hay una contradicción tradicional, pues la primera es una mala traducción del francés

Y desde luego en palabras «especiales», es decir, aquellas en que hay unas connotaciones ideológicas, la etimología, con el complemento de las razones de su uso, es fundamental:

Que contubernio u orquestar fueron fundamentales en el franquismo explican las connotaciones que han contraído; como usar el parte en lugar de diario hablado o la cruzada en lugar de la Guerra civil; o, en otro orden de cosas, trasterrado, neologismo creado por los republicanos españoles en el exilio, con una idea de mostrar que se habían llevado una parte de la tierra con ellos.

Pero la actuación etimológica puede ser también — digámoslo sin problemas - perversa, pues puede originar que la etimología cambie el significado de una palabra, frente al que tiene en la realidad:

Piafar (De or. inc.): 'Dicho del caballo: Alzar ya una mano, ya otra, dejándolas caer con fuerza y rapidez casi en el mismo sitio de donde las levantó» 59 Se evitó así 'ponerse nervioso el caballo', 'relinchar'.

Es un galicismo que entra a mediados del s. XIX (en fr. 'impacientarse'). Hay una idea en la Academia que es «PEDE FERIRE» y por esta etimología se cambia (cf. «Las caballerías relinchaban o piafaban entre la muchachas», Manuel Vicent).

Coma: hasta la $20^{\mathrm{a}}$ ed. inclusive se define como 'sopor más o menos profundo, dependiente de ciertas enfermedades, como congestión o hemorragia cerebral, diabetes, uremia, intoxicación, etc»., originado porque $\varkappa о \mu \alpha,-\alpha \tau \circ \sigma$ significaba 'sopor' en griego; pero no significa eso (por ello se ha cambiado), sino 'estado patológico que se caracteriza por la pérdida de la conciencia, la sensibilidad y la capacidad motora voluntaria', como síncope, lipotimia o colapso, originado por un fracaso circulatorio, no un sopor más o menos profundo.

\footnotetext{
${ }^{59}$ Real Academia Española, Diccionario de la lengua española, Madrid, Espasa Calpe, $22^{\mathrm{a}}$ edición, 2001, s. v. piafar.
} 
Avilantez 'audacia, insolencia', de vil. La emplea Ortega, Lázaro Carreter, Umbral.

No, es de avinentesa 'conveniencia', un catalanismo que entra en el s. XV y está en el XVI y los lexicógrafos de Autoridades interpretan mal a causa de creer que tiene que ver con vil. En Aut.: en la Guerra de Granada de Diego de Mendoza se lee: «Esto dio a los enemigos mayor avilanteza y a nosotros causa de dilación». Por eso hoy lo tenemos así.

Algo similar sucede también en relejar, relajar. La relación entre ellas hace que se determine la misma etimología para las dos palabras y esa etimología determina la definición que se da en relejar, releje, etc. Relejar está en el $D R A E$ desde 1817 como 'formar la pared relex o degenerar en él' (del cat. relleix 'cornisa o resalte', del cat. ant. lleixar 'dejar' (DECH, s. v. dejar)). En 1956 se da la etimología lat. RELAXARE; y en 1984, a causa de esa etimología, la primera acepción es 'relajar, aflojar o atenuar algunas cosas físicas o morales'.

La etimología puede ser fundamental como forma de creación en la lengua literaria. Cuando Ortega dice: «es obra de amor, porque significa generación, engendro de las unas cosas en las otras». Con este engendro, Ortega subvierte el significado de una voz y consigue un plus literario.

Pero hay un aspecto más. Sirvió en un momento de normativización para tomar decisiones que en una lengua que se normativiza podía crear problemas. ¿Qué seguir: el uso de Madrid, de Buenos Aires, de Zamora?; ¿Santa Teresa y Correas? (es decir, Castilla la Vieja) o Garcilaso y Valdés (es decir, Toledo) o Herrera (es decir, Sevilla)? Todos: el de la lengua del arte. Pero eso era una escapada cuando había que decidir si se utilizaba lenteja o lanteja:

Lanteja es la forma del español clásico — está en El Quijote-, pero la etimología lleva a lenteja.

Lagaña por legaña, aunque parezca un caso similar no lo es: lagaña es la forma preferida todavía en Autoridades (y se mantiene en algunos países de Hispanoamérica como la forma normal frente a legaña); legaña, por su parte, de origen no latino, motiva una extensa explicación en Corominas sobre el étimo del que deriva con el fin de explicar esa $e^{60}$.

Y como con ellas ocurre con bieldo o briendo, piedad o piadad (fijémonos en que tenemos piadoso).

El diccionario supo llenar de dobletes sus páginas: del tipo así - asín, jabalí - jabalín, bieldo - briendo; son dobletes uno de los cuales ha quedado caracterizado como rural. Pero para que eso haya ocurrido se ha dado el «truco» de ponerlo todo y distinguirlo no por el privilegio que procede de ser de un lugar o de otro, sino por lo que parecía una opción neutral, como era la de la etimo-

${ }^{60}$ J. Corominas con la colaboración de J. A. Pascual, Diccionario crítico y etimológico castellano e hispánico, Madrid, Gredos, 6 vols. s.v. legaña. 
logía: basta comparar un vocabulario dialectal con el diccionario académico para comprobar lo que se ha eliminado.

Con mejores o peores conocimientos del pasado, el hecho es que este pensamiento etimológico ha «ordenado» — lo digo con cierta ironía- de algún modo la lengua; pero no es ese orden lo que importa, sino haber dado con un argumento que quitaba hierro a las diferencias dialectales. Ante usos como los que hemos visto u otros como amaste - amastes, deber de - deber, se ha optado por una organización que no se adapta a lo que se dice en tal o cual lugar, sino a la razón etimológica.

\section{FINAL}

Es esto de la etimología una consideración imprescindible, incluso para explicar determinados cambios experimentados por nuestra lengua. A señalarlo aquí he querido dedicar la parte final de este artículo en el que quería mostrar el pensamiento etimológico de la Academia: un pensamiento que no termina en la confección del diccionario, sino que trasciende a la propia evolución de la lengua, porque tal evolución tiene algo que ver con las ideas de quienes la hablan $\mathrm{y}$, sobre todo, de quienes la codifican. 